\title{
CBL Gene Mutation
}

National Cancer Institute

\section{Source}

National Cancer Institute. CBL Gene Mutation. NCI Thesaurus. Code C136645.

A change in the nucleotide sequence of the CBL gene. 